\title{
Temperature and air pollution relationship during heatwaves in Birmingham, UK
}

\author{
Egide Kalisa $^{\text {a, b }}$, Sulaiman Fadlallah ${ }^{c^{*}}$, Mabano Amani ${ }^{\mathrm{d}}$, Lamek Nahayo ${ }^{\mathrm{e}}$, and Gabriel \\ Habiyaremye ${ }^{\mathrm{f}}$ \\ ${ }^{a}$ School of Geography, Earth and Environmental Sciences, University of Birmingham, Edgbaston, West Midlands B15 \\ 2TT, United Kingdom \\ ${ }^{b}$ School of Sciences, University of Rwanda, College of Science and Technology, Kigali-Rwanda \\ ${ }^{c}$ Mechanical Engineering Department, Auckland University of Technology, New Zealand \\ ${ }^{d}$ Centre for Functional Ecology, Department of Life Sciences, University of Coimbra, Largo Marquês de Pombal, \\ 3004-517 Coimbra, Portugal \\ ${ }^{e}$ State Key Laboratory of Desert and Oasis Ecology, Xinjiang Institute of Ecology and Geography, Chinese Academy \\ of Sciences, 818 South Beijing Road \\ ${ }^{f}$ Lancaster Environment Centre, Lancaster University - Lancaster LA1 4YQ, United Kingdom
}

\begin{abstract}
While temperature has long been known as a catalyst for pollutant to be more airborne, it is unclear how an increase in temperature impacts on air pollution during heatwaves. Through a regression analysis the relationship between ozone $\left(\mathrm{O}_{3}\right)$, particulate matter $\left(\mathrm{PM}_{10}\right.$, particles less than $10 \mu \mathrm{m}$ in diameter), nitrogen dioxide $\left(\mathrm{NO}_{2}\right)$, and temperatures in urban and rural areas of Birmingham, it was found that during heatwaves, all pollutant levels rose at each site, with the maximum temperature coinciding with the peak of $\mathrm{O}_{3}$ and $\mathrm{PM}_{10}$. These findings established that the influence of temperature on air pollution did not change according to rural and urban locations although air pollutants $\left(\mathrm{O}_{3}, \mathrm{NO}_{2}\right.$, and $\left.\mathrm{PM}_{10}\right)$ increased with increasing temperatures particularly during heatwaves. However the variation in the amount of ozone, altered by more than $50 \%$ according to increases in temperature. This matches studies where the incidence of high levels of pollution have conclusively been found to be much more prevalent during heatwaves of a long duration. The implications of these findings are important to long-term prevention in the framework of heatwave plans and when there is a heatwave forecast, additional measures to reduce air pollutant concentrations may be appropriate to trigger emergency response.
\end{abstract}

Keywords: Heatwave; Temperature; Ozone; Nitrogen dioxide; Particulate matter less than 10 $\mu \mathrm{m}$.

\footnotetext{
*Address correspondence to Sulaiman Fadlallah, Auckland University of Technology, Mechanical Engineering Department, New Zealand. E-mail: sulaiman.fadlallah@aut.ac.nz

Phone: +64 2108242625.
} 


\section{Introduction}

The impact of worsening air quality and extreme weather events, such as heatwaves, are increasingly affecting people in both hemispheres. Heatwaves have long been known as an important driver of air pollutants, inducing various health, environmental, and economic impacts (Cheval et al., 2009; García-Herrera et al., 2010). Air pollutants whose concentrations and impacts are known to be affected by heatwaves include particulate matter $(\mathrm{PM})$, ozone $\left(\mathrm{O}_{3}\right)$ and nitrogen dioxide $\left(\mathrm{NO}_{2}\right)$. These pollutants being emitted into atmosphere from a variety of natural and anthropogenic sources, are a major threat to human health (World Health Organization, 2010). The concentration of these pollutants in ambient air, depends on the amount of emission and the ability of the atmosphere to absorb or disperse these pollutants (World Health Organization, 2010).

Since meteorological variables such as temperature and concentrations of air pollutants vary on a daily basis, it is important to consider their relationship in the planetary boundary layer, since the atmosphere is the medium in which air pollutants are transported away from the source. Lee et al. (2006) indicated that during photochemical pollution episodes, air pollutants $\left(\mathrm{O}_{3}, \mathrm{NO}_{2}\right.$, and $\left.\mathrm{PM}_{10}\right)$ are the result of a mixture of various meteorological effects and chemical reactions. These pollutants are of the greatest health concern, as they may be exacerbated during heatwaves (Analitis et al., 2014; Fouillet et al., 2006; Johnson et al., 2004), and not only cause sensitive individuals to be stressed by high temperatures, but be the cause of mortality during heatwaves (Analitis et al., 2014). Unusual hot weather during summer led to elevated air pollutants during the heatwaves that occurred in Athens, Greece between June and July 2007 (Fischer et al., 2004). Theoharatos et al. (2010) found a significant correlation between heatwaves and average hourly concentrations of $\mathrm{O}_{3}, \mathrm{NO}_{2}$ and $\mathrm{SO}_{2}$ in Athens. Similarly the combination of elevated air pollution 
levels and high temperatures has been implicated in the increase of urban heat island (UHI) and air pollution in London, England (McMichael et al., 2003; Rooney et al., 1998).

Heatwaves are particularly intense in urban areas, where surface characteristics alter temperature difference between urban and rural areas. This changes is due to low vegetation in cities production of anthropogenic heat and air flow caused by urban infrastructures such as buildings and asphalt street (Bibri \& Krogstie, 2017). Mirzaei, (2015) indicated that extreme air temperature of a city (UHI) increases the heat and air pollution related mortality and raised energy demand of building for cooling, which in turn leads to an increase in air pollutants and greenhouse gases. Despite this, several studies have shown that the sustainable urban planning or smart city such as green roofs and cool pavements could significantly reduce both $\mathrm{UHI}$ and air pollution especially $\mathrm{O}_{3}, \mathrm{NO}_{2}$, and PM$_{10}$ (Bibri \& Krogstie, 2017; McDonald et al., 2007; Silva, Khan, \& Han, 2018; Yang, Yu, \& Gong, 2008).

Previous studies between temperature and air pollution during heatwaves (Fouillet et al., 2006; Fischer et al., 2004) have only explored the role of air pollution in modifying the effects of heatwaves on mortality. There is a dearth of research studies that investigated the relationship between temperature and air pollution during heatwaves without the consideration of the effects of mortality. In addition, there seems to be no research into the spatial relationship of temperature and air quality during heatwaves, such as between urban and rural areas in England. The objectives of this study are to: (1) assess the relationship between temperature and air pollution during heatwaves, (2) quantify the impact of temperature on air pollutants (namely ozone $\left(\mathrm{O}_{3}\right)$, particulate matter $\left(\mathrm{PM}_{10}\right)$ and nitrogen dioxide $\left(\mathrm{NO}_{2}\right)$ and finally, (3) investigate the difference of that impact 
between urban and rural areas of Birmingham in the United Kingdom during heatwave events identified between 2003 and 2013 .

\section{Materials and Methods}

\subsection{Study location}

Data used in this study were collected in the Birmingham metropolitan city in the United Kingdom. Birmingham was selected as study location to be representative of a typical population exposure as the largest and most populous British City outside London located in the West Midlands region. This study employed eleven years data series (2003-2013) of $\mathrm{O}_{3}, \mathrm{NO}_{2}$, and $\mathrm{PM}_{10}$ and meteorological data (Temperature). Birmingham Tyburn (52.51 N, -1.83W) and Harwell (51.57 $\mathrm{N},-1.325283 \mathrm{~W}$ ) air quality monitoring stations provided respectively urban and rural data (Fig. 1). Edgbaston (52.46 N, $-1.91 \mathrm{~W})$ and Coleshill (52.48 N, -1.689 W) weather stations provided respectively urban and rural meteorological data used in this study.

\subsection{Air quality data}

Historical air quality data $\left(\mathrm{O}_{3}, \mathrm{NO}_{2}\right.$, and $\left.\mathrm{PM}_{10}\right)$ data with both urban and rural backgrounds required for this study were obtained from the Department for Environment, Food and Rural Affairs (DEFRA) (www.defra.gov.uk). Birmingham Tyburn is an urban background air quality monitoring station situated to the North-East of Birmingham City centre, near the Tyburn Road (A38) within $6 \mathrm{~km}$ of the city centre, a site typical of the urban environment. This station was chosen because a comprehensive range of measurements had been reliably collected over time. Harwell is located in a rural location, Harwell Science Centre in Oxfordshire, in the South Eastern 
part of England. The site is surrounded by fields and is considered as representative of a rural location monitoring station (Charron et al., 2007). The nearest road is on the east of the science park with access to only buildings. The nearest trees are at a distance of 200-300 m from the monitoring station. Harwell is situated at an altitude of $126 \mathrm{~m}$ in the South East of England. Although Harwell air quality station is not located in the Birmingham metropolitan area, it was chosen for this study because Harwell was seen as the best choice to provide rural air quality data for this 11-year period - previous studies have used data from Harwell station to represent reliable rural data over the United Kingdom. The first assessment was of the availability of daily concentrations of ozone (maximum 8-hour running average), nitrogen dioxide (the daily maximum value of the 1-hour mean) and particulate matter (mean, 24 hours). There was no air quality data for $\mathrm{NO}_{2}$ for 2013 at Harwell monitoring station and $\mathrm{NO}_{2}$ and $\mathrm{PM}_{10}$ at Birmingham Tyburn in 2006.

\subsection{Temperature data}

The daily maximum temperature data from 1 January 2003 to 31 December 2013 were obtained from two synoptic weather stations situated in Coleshill (approx. $12 \mathrm{~km}$ from city centre, representing a rural background) and Edgbaston (approx. $4 \mathrm{~km}$ from city centre, representing an urban background) (see British Atmospheric Data Centre (http://badc.nerc.ac.uk)). The weather stations (urban \& rural) were chosen based on data availability over the 11-years period, with reference to the literature that has previously used similar stations (Johnson, 1985; Tomlinson et al., 2012).

\subsection{Heatwave definition}


One of the challenges in this study was to define a heatwave day, as the concept of a heatwave has no universal definition (Meehl et al., 2000), being dependent on the average climate for each region in question. In this study, the definition of a heatwave was much closer to the definition by the World Meteorological Organization (WMO) with some modification. According to the WMO, a heatwave is the phenomenon during which the daily maximum temperature for at least five consecutive days exceeds the average maximum temperature by $5{ }^{\circ} \mathrm{C}$, considering the period between 1961 and 1990 as the normal measuring period (Frich et al., 2002). Heatwaves are likely to occur during summer months, thus, we have analyzed the historical trend of an ozone season typically from May 1st to September 30th (U.S. EPA, 2009). The data analysis focused on the extended summer months starting from May to September (known as summer months) (Shen et al., 2016), during which the probability to observe a heatwave was highest (Air Quality Expert Group, 2005). In this study, heatwave was defined as phenomenon during which the daily maximum temperature for at least five consecutive days exceeds the average maximum temperature by $6{ }^{\circ} \mathrm{C}$. In addition to heatwaves identified in rural and urban areas, this study has also noted some hot day episodes observed in hottest years in Birmingham. We define hot day as an episode of one to four consecutive days that occurred before or after the heatwave period with temperature above or equal to $25^{\circ} \mathrm{C}$.

\subsection{Data analysis}

The relationship between daily mean temperature and air pollution levels during heatwave periods for Birmingham was determined using a simple linear regression model (linear correlation model) to highlight the possible correlation between temperature and each of the air pollutants. Statistical analysis was performed using Statistical Analysis Software (SAS, version 9.4 by SAS institute Inc. Cary.INC. USA). 


\section{Results and Discussion}

\subsection{Hot days and heatwave days}

In this paper, the discussion presented only focused on severe heatwaves (2003, 2006 and 2013) where high intensity and long duration of heatwaves were observed (Table 1 and Table 2). In all heatwaves identified in rural and urban areas, the temperatures ranged from $26.9-34.1^{\circ} \mathrm{C}$. Based on a hot day definition, 135 hot days were observed in rural areas and only 109 hot days were observed in urban areas (Table 5). Most hot days observed during the eleven years occurred in July for both sites, followed by June and August, respectively. Based on heatwave definitions applied in this study, 8 heatwave periods were identified in the rural area (Table 1) and 7 heatwaves in the urban area (Table 2). Most severe heatwaves with highest intensity and longest duration were found in August 2003, July 2006 and July 2013 in both urban and rural areas (Table 5). The highest frequency of hot days (more than 5 days in a month) observed between 2003 and 2013 was in August 2003 (45.5\%), July 2006 (55.2\%) and July 2013 (88.2\%) in both rural and urban areas (Table5). Comparing the most intense heatwaves (2003, 2006 and 2013) observed, August 2003 displayed the highest maximum temperatures for both urban and rural areas (Fig. 2). The heatwave in 2003 was the hottest heatwaves year, however, in terms of duration; the 2006 heatwave included 21 consecutive days with a temperature above $25{ }^{\circ} \mathrm{C}$ compared to 8 days in 2003 and 11 days in 2013 for rural areas (Table 1). The heatwave duration and intensity can be important factors for a significant increase in the concentration of air pollutants particularly on $\mathrm{O}_{3}$ (Theoharatos et al., 2010). The results (Table 6) show that temperature levels were significantly high in rural areas rather than urban areas ( $\mathrm{p}=0.0156)$ during summer months (May 2003 to September 2013). This is likely due to urban areas being considerably warmer than the surrounding suburban areas due to the so-called Urban Heat Island (UHI). Pearce et al. (2011) state that urban areas are warmer than 
their surrounding areas due to the characteristics of urban surface, radiative trapping effect, significant human activity, heat release, high heat capacity and the lack of green space (vegetation and moisture space). However, the use of this metric (daily maximum temperature), may explain why high temperatures were not observed in urban areas, as it might be expected due to the behaviour of urban heat island (UHI) which occurs normally during night time. In addition, summer temperatures dry the ground in rural areas, which enhances the radiation from the sun to be reflected back to the atmosphere and increases the daytime temperature. Research in the UK showed that UHI enhances night-time temperatures, especially during heatwave periods (Tomlinson et al., 2012; Oke, 1973). Many cities like Birmingham reported air temperatures that are warmer in urban area than surrounding areas. Tomlinson et.al (2012) indicated that Birmingham UHI presented a magnitude of more than $4.5{ }^{\circ} \mathrm{C}$ on a heatwave day in 2006 and Heaviside et al. (2015) showed a magnitude of up to $7^{\circ} \mathrm{C}$ in August 2003. Again, the albedo (the amount of incident radiation or light that is reflected by a surface) can have a significant effect on air temperature, with high temperatures associated with dark, low albedo surfaces such as tarmac (Mirzaei, 2015). High albedo surfaces reflect back much of the incoming light from the sun into the atmosphere while low albedo absorbs more energy from the sun. Rural areas have high albedo because the daytime temperature becomes high once reflected in the atmosphere while urban areas (urban materials) absorb heat during the day and release it during the night. Furthermore, Johnson (1985), has indicated that the level of the heating and cooling of urban and rural areas could be explained by the sky view factor (SVF), which is the amount of the sky visible from the ground. For example, the sky view factor controls the radiation balance in Birmingham City centre because of the tall buildings. The cooling rates reduce with a decrease in SVF $(r=-0.83)$. Therefore, Birmingham was found to heat up and cool down more than its surrounding rural areas. In addition, 
most of the rural areas of Birmingham are partially similar to urban areas, thus there is not much variation between the two areas. These findings are consistent with a recent study published by the Royal Meteorology Society on Birmingham UHI (Tomlinson et al., 2012). Unwin (1980) also used a similar weather station (Edgbaston) in a study comparing daily minimum and maximum temperature at two sites, Edgbaston and Elmdon. The results showed that the average temperature (daily maximum) was cooler at Edgbaston, which represents an urban area compared to Elmdon that represents rural area where the heat island effect was due to nighttime minimum temperature at Edgbaston. This research supports similar findings in this study that a daytime cool urban island pervades through Birmingham (Unwin, 1980).

\subsection{Air pollution and heatwaves}

\subsubsection{Temperature and air pollution relationship during heatwaves of August 2003}

During the past 11 years, the mean concentration of $\mathrm{O}_{3}(\mathrm{p}<0.0001)$ and temperature $(\mathrm{p}=0.0156)$ (Table 3) were significantly higher in rural than urban areas. However, the mean concentrations of $\mathrm{NO}_{2}$ was significantly higher in the urban than rural area $(\mathrm{p}<0.0001)$. Only $\mathrm{PM}_{10}$ did not show a statistically significant difference of mean concentration between rural and urban areas $(\mathrm{p}=$ 0.0765). The comparison of mean concentration of air pollutants $\left(\mathrm{O}_{3}, \mathrm{NO}_{2}\right.$, and $\left.\mathrm{PM}_{10}\right)$ and temperature between urban and rural sites for all 11 years are shown in the Table 3. Details by each year (2003 to 2013) on the comparison of mean concentration of air pollutants $\left(\mathrm{O}_{3}, \mathrm{NO}_{2}\right.$, and $\left.\mathrm{PM}_{10}\right)$ and temperature in rural and urban areas are presented in the Table 4. During 2003 the mean concentration of $\mathrm{O}_{3}$ and $\mathrm{NO}_{2}$ were significantly different between urban and rural areas (Table 6). Temperature, $\mathrm{O}_{3}, \mathrm{NO}_{2}$, and $\mathrm{PM}_{10}$ concentrations on days with heatwaves are significantly higher than those non-consecutive "hot" days. Additionally, $\mathrm{O}_{3}$ concentrations rose at both urban and rural sites and coincided with the peak of the maximum temperature. The peaks 
of temperature coincided with the peak of $\mathrm{O}_{3}, \mathrm{NO}_{2}$, and $\mathrm{PM}_{10}$ during 9th August in both rural and urban areas (Fig. 2). During the same month, the results of the correlation between temperature and air pollution was only significant for $\mathrm{O}_{3}\left(\mathrm{R}^{2}=0.44, \mathrm{n}=28, \mathrm{p}<0.0001\right)$ and $\mathrm{PM}_{10}\left(\mathrm{R}^{2}=0.39, \mathrm{p}\right.$ $=0.0001)$ in rural areas. In the urban area the influence of temperature on $\mathrm{NO}_{2}\left(\mathrm{R}^{2}=0.20, \mathrm{n}=31\right.$, $\mathrm{p}=0.0068)$ and $\mathrm{O}_{3}\left(\mathrm{R}^{2}=0.54, \mathrm{n}=30, \mathrm{p}<0.0001\right)$ was significant with a positive correlation except for $\mathrm{PM}_{10}$. These findings are consistent with those previously reported in the heatwaves of the US (Lee et al., 2006) and Netherlands (Tomlinson et al., 2012). Previous studies report an indirect relationship between air pollution and temperature during heatwaves, by comparing effects of air pollution and temperature on mortality during heatwave periods (Analitis et al., 2014; Filleul et al., 2006; Stedman, 2004) and not heatwave periods (Carslaw et al., 2007; Pearce et al., 2011). These studies support our present findings.

\subsubsection{Temperature and air pollution relationship during heatwaves of June -July 2006}

During 2006, 3 episodes of heatwaves were observed in each urban and rural area (Tables 1 and 2). The year 2006 was characterised by long duration heatwaves compared to $2003 \& 2013$ ). Generally, the $\mathrm{O}_{3}, \mathrm{NO}_{2}$, and $\mathrm{PM}_{10}$ concentrations on days with heatwaves were elevated compared to other hot days, where heatwaves were not observed (Fig. 3). This reflects the build-up effect from the extended period of high temperature during heatwave events. During June 2006, in rural areas, increased temperatures resulted in increased air pollutants. The results on the correlation between temperature and air pollution showed a significant and positive correlation between temperature and $\mathrm{O}_{3}\left(\mathrm{R}^{2}=0.54, \mathrm{p}<0.0001\right)$ and $\mathrm{PM}_{10}\left(\mathrm{R}^{2}=0.30, \mathrm{n}=30, \mathrm{p}<0.0001\right)$. During July 2006 in the rural area, similar findings were observed with a positive correlation between temperature and $\mathrm{PM}_{10}\left(\mathrm{R}^{2}=0.40, \mathrm{p}<0.0001\right)$; and $\mathrm{O}_{3}\left(\mathrm{R}^{2}=0.80, \mathrm{p}<0.0001\right)$. In the urban area, 
June and July 2006 showed the same evolution with peaks situated in periods of high temperature. Statistically significant variation and positive correlation were observed between temperature and $\mathrm{O}_{3}(\mathrm{R}=0.48, \mathrm{p}<0.0001)$ and $\mathrm{PM}_{10}\left(\mathrm{R}^{2}=0.36, \mathrm{n}=30, \mathrm{p}=0.0002\right)$ in June 2006 and similar findings were observed in July 2006 for $\mathrm{O}_{3}\left(\mathrm{R}^{2}=0.76, \mathrm{n}=31, \mathrm{p}<0.0001\right), \mathrm{PM}_{10}\left(\mathrm{R}^{2}=0.38, \mathrm{n}=31, \mathrm{p}=\right.$ $0.0001)$ and $\mathrm{NO}_{2}\left(\mathrm{R}^{2}=0.54, \mathrm{n}=25, \mathrm{p}=0.0015\right)$. Figs. 3 and 4 show that 2006 heatwaves were much longer in terms of duration, which can be attributed to the large number of mortalities recorded in the Birmingham during the 2006 heatwave, than August 2003 (Vardoulakis and Heaviside, 2012). The heatwave duration and intensity can be important factors for a significant increase in the concentration of air pollutants particularly on $\mathrm{O}_{3}$ (Theoharatos et al., 2010).

\subsubsection{Temperature and air pollution relationship during heatwaves of July 2013}

The heatwave period observed in 2013 occurred during July. However, the influence of temperature on air pollution was only significant on $\mathrm{O}_{3}$ in rural areas (Fig. 5) $\left(\mathrm{R}^{2}=0.51, \mathrm{n}=31\right.$, $\mathrm{p}<0.0001$. Figs. 5 shows that pollution variation was not instantly linked to the variation of temperature. In fact, there was a time lapse between the increase or decrease of temperature and the increase or decrease of air pollution. This suggests the effect of both current and previous day's temperature on air pollution readings.

\subsection{Correlation analysis of air pollution and all intense heatwaves identified in 2003, 2006 and 2013}

Based on the analysis of simple linear regression, the relationship between air pollutants $\left(\mathrm{O}_{3}, \mathrm{NO}_{2}\right.$, and $\mathrm{PM}_{10}$ ) and temperature during all intense heatwaves that happened in 2003, 2006 and 2013 are presented in Fig. 6. In all intense heatwaves during the three years (2003, 2006 and 2013), the maximum temperatures positively correlated with most air pollutants (Fig. 6). However, this 
correlation was weak for $\mathrm{NO}_{2}$. Observation-based statistical analysis showed that temperature affects all three-air pollutants, particularly for $\mathrm{O}_{3}$ and $\mathrm{PM}_{10}$. Strong correlation was also observed between these pollutants and temperature during heatwaves in both urban and rural areas. The results of this study indicated that the correlation of $\mathrm{O}_{3}$ with daily maximum temperature $\left(\mathrm{R}^{2}=\right.$ 0.40, $\mathrm{p}=0.0001)$ was much higher than $\mathrm{PM}_{10}\left(\mathrm{R}^{2}=0.32, \mathrm{p}<0.0001\right)$ and $\mathrm{NO}_{2}\left(\mathrm{R}^{2}=0.04, \mathrm{p}=\right.$ 0.0566) during intense heatwaves identified in rural areas (Fig. 6). In Fig.4 the temperature strongly correlates with $\mathrm{NO}_{2}$ during the heatwave of July 2006 in which the correlation coefficient $\mathrm{R}^{2}$ was larger than 0.50 . In all intense heatwaves during the three years, the maximum temperatures positively correlated with most air pollutants (Fig. 6). However, this correlation was weak for $\mathrm{NO}_{2}$. A peak in $\mathrm{NO}_{2}$ was observed at the beginning of the heatwave, on 5 August in rural areas and 3 August 2003 in urban areas. The annual number of the exceedances of the air quality standards (40 $\mu \mathrm{g} / \mathrm{m}^{3}$ annual mean), matching the annual number of heatwave days. This could be attributed to the atmospheric conditions that usually prevail during heatwave days. Stagnation of air masses is usually observed during heatwaves, favouring the accumulation of particles and $\mathrm{O}_{3}$ precursors $\left(\mathrm{NO}_{2}\right)$ (Tressol et al., 2008). The comparison of influence of temperature on air pollution, between rural and urban areas during all intense heatwaves identified in 2003, 2006 and 2013 indicated that there was no significant difference between both areas.

\subsubsection{Ozone $\left(\mathrm{O}_{3}\right)$}

The maximum $\mathrm{O}_{3}$ concentration was recorded at Harwell rural air quality station during the 2003 heatwave $\left(200 \mu \mathrm{g} / \mathrm{m}^{3}\right)$ rather than at the Birmingham Tyburn station (urban) $\left(173 \mu \mathrm{g} / \mathrm{m}^{3}\right)$. These concentrations coincide with the daily maximum temperature in rural $\left(34.1^{\circ} \mathrm{C}\right)$ and urban areas $\left(33.2{ }^{\circ} \mathrm{C}\right)$. The concentration of $\mathrm{O}_{3}$ was significantly lower in the urban than in the rural area 
( $<<0.0001)$. Statistically significant positive correlations were found between temperature and $\mathrm{O}_{3}$ in all the heatwaves identified in the rural area, but the level of correlation was found to be moderate in the urban area. The fact that most of the times ozone levels are higher in rural areas than in cities can be explained by ozone degradation by its precursors (NOx) (Simon, Reff, Wells, Xing, \& Frank, 2015). Ozone is a secondary pollutant, which means it is not directly emitted by traffic or industry emissions in cities, but it is formed on hot days by the influence of solar radiation to become more airborne. This degradation occurs more often in cities than in rural areas, because there is more NO in cities (Wałaszek, Kryza, \& Werner, 2018). The $\mathrm{O}_{3}$ concentrations were found to increase with increasing daily maximum temperature. This phenomenon exists because the elevated concentration for nitrogen oxides helps the removal of $\mathrm{OH}$ radicals, through the reaction with $\mathrm{NO}_{2}$ (Qian et al., 2012). In addition, the peaks of $\mathrm{O}_{3}$ during the heatwave are due to favourable temperatures and plenty of sunlight that promote the photochemical reaction (Katsouyanni et al., 2001). Furthermore, UHI can also contribute to the production and the dispersion of $\mathrm{O}_{3}$ (Chaxel and Chollet, 2009). We found that when the temperature was lower especially during no heatwave periods, $\mathrm{O}_{3}$ concentration did not correlate with the air temperature. However, strong correlation was observed during heatwave periods of a longer duration (Fig. 4). There are various plausible explanations for a synergistic association between elevated temperature, and air pollutants. Processes in the atmosphere in the presence of sunlight, generate ozone and a proportion of particles (secondary particles) and primary emitted pollutants. Since Sunlight is associated with high temperatures, there is likely to be increased production of secondary pollutants during warm seasons (Elminir, 2005; Tressol et al., 2008). During heatwaves, the air becomes stagnant, and traps emitted pollutants, often resulting in increases in ground level $\mathrm{O}_{3}$ (Solberg et al., 2008; Monks et al., 2015). These findings are consistent with previous studies that reported strong correlation 
with temperature during heatwaves (Johnson et al., 2004; Chaxel and Chollet, 2009; Heal et al., 2013; Huang et al., 2010; Dawson et al., 2007).

\subsubsection{Particulate matter $\left(P M_{10}\right)$}

Air pollutants are generally more concentrated in urban areas than in rural areas due to large emissions from human activities (Hewitt and Jackson, 2009; Jacobson, 2012). This study found that the average concentration of $\mathrm{PM}_{10}$ were higher in urban than in rural areas during heatwave years recorded in the Birmingham (Table1). Temperature increase led to the increase of the level of $\mathrm{PM}_{10}$. In this study, the mean concentration of $\mathrm{PM}_{10}$ increased with rising temperatures during heatwaves in both urban and rural areas. This occurs because warm weather induces the formation of secondary fine particles, therefore increased temperatures result in increased $\mathrm{PM}_{10}$ (Dawson et al., 2007; Tai et al., 2010; Massey et al., 2012). The higher concentration of $\mathrm{PM}_{10}$ in urban areas than in rural areas is more likely due to more emission sources in urban areas. Consequently, this results in turbulence flow and elevated $\mathrm{PM}_{10}$ levels in congested areas with tall buildings, which stop air and trap pollutants. For example, Birmingham city centre has many tall buildings, which stop airflow and trap pollutants often resulting in increases in ground level of $\mathrm{PM}_{10}$. In addition, $\mathrm{PM}_{10}$ increases in urban areas because of heavy road traffic emissions and road transport emissions (tyre pipe, brake wear, and re-suspension) (Dore et al., 2003; Barlow et al., 2007). These findings are in agreement with previous studies (Analitis et al., 2014; Vardoulakis and Kassomenos, 2008; Air Quality Expert Group, 2005; Pearce et al., 2011; Elminir, 2005). Mues et al. (2012) investigating the effect of the meteorological conditions in the extreme European summer 2003 on the concentration of $\mathrm{PM}_{10}$, observed that the concentrations of $\mathrm{PM}_{10}$ increased during weather conditions with high daily maximum temperature. Pollution levels can therefore be further increased during heatwave because of the atmospheric conditions that prevail leading to the 
accumulation of pollutants (Tressol et al., 2008). This infers that during the summer episodes when the hot weather is associated with slow wind speed, the presence of high temperatures increases the likelihood of $\mathrm{O}_{3}$ and $\mathrm{NO}_{2}$ emissions. High ambient temperatures support the production of secondary aerosols. Thus, the increase of the concentration of $\mathrm{NO}_{2}$ and $\mathrm{O}_{3}$ during the summer can be accredited to the production of secondary aerosols (Elminir, 2005). Furthermore, in Birmingham, the concentration of $\mathrm{PM}_{10}$, was found to be higher during low wind speed (poor dispersion conditions) and this is thought to be a result of atmospheric stability and a reduced mixing of air (Vardoulakis and Kassomenos, 2008). Typically the concentration of $\mathrm{PM}_{10}$ during warm seasons in Athens has been attributed to relative contribution of secondary and natural particles during hot and dry days (Kassomenos et al., 2014).

\subsubsection{Nitrogen dioxide $\left(\mathrm{NO}_{2}\right)$}

The results of this study as shown in Table 1 and 2 show that the mean concentration of $\mathrm{NO}_{2}$ was significantly higher in urban $\left(51.7 \mu \mathrm{g} / \mathrm{m}^{3}\right)$ rather than rural areas $\left(18.4 \mu \mathrm{g} / \mathrm{m}^{3}\right)$. The main reason for this higher concentration in urban areas was due to large emissions from traffic congestion, which is greater in the urban than surrounding areas. Defra (2004) and US EPA (2009) have indicated that over the UK, the high concentration of $\mathrm{NO}_{2}$ is elevated in most urban areas particularly at kerbside locations. It has been reported that local dispersion and temperature play an important role (Carslaw et al., 2007). However, less research has been directed to the meteorological link (temperature) for $\mathrm{NO}_{2}$ during heatwave events. Pearce et.al (2011) report that when the temperature rises above $35^{\circ} \mathrm{C}$, nitrogen dioxide increases by about $120 \%$. It has been reported that in Cairo (Egypt) the yearly distribution of the monthly average concentration of nitrogen dioxide levels, peaks during the summer, particularly in July $103 \mu \mathrm{g} / \mathrm{m}^{3}$, and from August

to December, the monthly average concentration of $\mathrm{NO}_{2}$ decreases from about 82 to $62 \mu \mathrm{g} / \mathrm{m}^{3}$ (Elminir, 2005). In Fig.4 the temperature strongly correlates with $\mathrm{NO}_{2}$ during the heatwave of July 
2006 in which the correlation coefficient $\mathrm{R}^{2}$ was larger than 0.50 . A peak in $\mathrm{NO}_{2}$ was observed at the beginning of the heatwave, on 5 August in rural areas and 3 August 2003 in urban areas. The annual number of the exceedances of the air quality standards $\left(40 \mu \mathrm{g} / \mathrm{m}^{3}\right.$ annual mean), matching the annual number of heatwave days. This could be attributed to the atmospheric conditions that usually prevail during heatwave days. Stagnation of air masses is usually observed during heatwaves, favouring the accumulation of particles and $\mathrm{O}_{3}$ precursors $\left(\mathrm{NO}_{2}\right)$ (Tressol et al., 2008). These findings indicate that the influence of temperature on $\mathrm{NO}_{2}$ is much more effective in heatwaves than other hot days, due to the higher temperature range. However, the influence of temperature on $\mathrm{NO}_{2}$ during a heatwave is low compared to ozone and $\mathrm{PM}_{10}$. In conclusion, nitrogen dioxide concentration increases with increasing temperature during heatwave events, which strongly agrees with previous related studies (Rooney et al., 1998; Stedman, 2004; Pearce et al., 2011).

\section{Conclusion}

This article has examined the relationship between temperature and air pollution during heatwave periods in Birmingham. A heatwave was defined by taking both intensity and duration into account. Overall, the results indicate that there was a linear relationship and positive correlation between temperature and air pollution during the heatwaves and that the relation between temperature and air pollution was more evident for high intensity and long duration heatwaves. 
The variation of average air pollution levels in relation with heatwave duration, exhibited a peak that was more pronounced for O3. The implications of these findings are important for policy measures; for example, when there is a heatwave forecast, additional measures to reduce air pollutant concentrations may be appropriate to trigger emergency response, and this measure can be applicable either in urban or rural environments. Based on our findings, it would seem unwise to attempt to relate health effects such mortality for assessing the correlation between temperature and air pollution. However, when assessing health effects of high temperature and air pollution, this should be assessed during heatwave periods. Air pollution is so closely related to temperature, removing one variable (air pollutants or temperature), could reduce the effect of the other variable substantially. Thus, the correlation between temperature and air pollution cannot be assessed based on cases of health effect.

\section{Acknowledgments}

We thank the Department for Environment, Food and Rural Affairs (DEFRA) and the British Atmospheric Data Centre (BADC) for providing the data sets that were required for this study. E.K. is the recipient of a Rwanda Education Board and University of Birmingham Scholarship for postgraduate study.

\section{Conflicts of Interest}

The authors declare that there is no conflict of interest regarding the publication of this article. 


\section{References}

Cheval, S., Dumitrescu, A., \& Bell, A. (2009). The urban heat island of Bucharest during the extreme high temperatures of July 2007. Theoretical and Applied Climatology, 97(3-4), 391-401.

García-Herrera, R., Díaz, J., Trigo, R. M., Luterbacher, J., \& Fischer, E. M. (2010). A review of the European summer heat wave of 2003. Critical Reviews in Environmental Science and Technology, 40(4), 267-306.

World Health Organization, (2010). WHO guidelines for indoor air quality: Selected pollutants.

Lee, J. D., Lewis, A. C., Monks, P. S., Jacob, M., Hamilton, J. F., Hopkins, J. R., Watson, N. M., Saxton, J. E., Ennis, C., Carpenter, L. J., Carslaw, N., Fleming, Z., Bandy, B. J., Oram, D. E., Penkett, S. A., Slemr, J., Norton, E., Rickard, A. R., Whalley, L. K, Heard, D. E., Bloss, W. J., Gravestock, T., Smith, S. C., Stanton, J., Pilling, M. J., \& Jenkin, M. E. (2006). Ozone photochemistry and elevated isoprene during the UK heatwave of August 2003. Atmospheric Environment, 40(39), 7598-7613.

Analitis, A., Michelozzi, P., D’Ippoliti, D., de’Donato, F., Menne, B., Matthies, F., Atkinson, R. W., Iñiguez, C., Basagaña, X., Schneider, A., Lefranc, A., Paldy, A., Bisanti, L., \& Katsouyanni, K. (2014). Effects of heat waves on mortality: Effect modification and confounding by air pollutants. Epidemiology, 25(1), 15-22.

Fouillet, A., Rey, G., Laurent, F., Pavillon, G., Bellec, S., Guihenneuc-Jouyaux, C., Clavel, J., Jougla, E., \& Hémon, D. (2006). Excess mortality related to the August 2003 heat wave in France. International Archives of Occupational and Environmental Health, 80(1), 16-24.

Johnson, H., Kovats, S., McGregor, G., Stedman, J., Gibbs, M., Walton, H., \& Cook, L. (2004). The impact of the 2003 heat wave on mortality and hospital admissions in England. Epidemiology, 15(4), S126.

Theoharatos, G., Pantavou, K., Mavrakis, A., Spanou, A., Katavoutas, G., Efstathiou, P., Mpekas, P., \& Asimakopoulos, D. (2010). Heat waves observed in 2007 in Athens, Greece: Synoptic conditions, bioclimatological assessment, air quality levels and health effects. Environmental Research, 110(2), 152-161.

McMichael, A. J., Campbell-Lendrum, D. H., Corvalan, C. F., Ebi, K. L., Githeko, A. K., Scheraga, J. D., \& Woodward, A. (2003). Climate change and human health: Risks and responses. World Health Organization, Geneva.

Rooney, C., McMichael, A. J., Kovats, R. S., \& Coleman, M. P. (1998). Excess mortality in England and Wales, and in Greater London, during the 1995 heatwave. Journal of Epidemiology \& Community Health, 52(8), 482-486.

Fischer, P. H., Brunekreef, B., \& Lebret, E. (2004). Air pollution related deaths during the 2003 heat wave in the Netherlands. Atmospheric Environment, 38(8), 1083-1085. 
Charron, A., Birmili, W., \& Harrison, R. M. (2007). Factors influencing new particle formation at the rural site, Harwell, United Kingdom. Journal of Geophysical Research: Atmospheres, 112, D14210.

Johnson, D. B. (1985). Urban modification of diurnal temperature cycles in Birmingham, UK. International Journal of Climatology, 5(2), 221-225.

Vardoulakis, S., \& Kassomenos, P. (2008). Sources and factors affecting PM 10 levels in two European cities: Implications for local air quality management. Atmospheric Environment, 42(17), 3949-3963.

Tomlinson, C. J., Chapman, L., Thornes, J. E., \& Baker, C. J. (2012). Derivation of Birmingham's summer surface urban heat island from MODIS satellite images. International Journal of Climatology, 32(2), 214-224.

Meehl, G. A., Karl, T., Easterling, D. R., Changnon, S., Pielke, R., Changnon, D., Evans, J., Groisman, P. Y., Knutson, T. R., Kunkel, K. E., Mearns, L. O., Parmesan, C., Pulwarty, R., Root, T., Sylves, R. T., Whetton, P., \& Zwiers, F. (2000). An introduction to trends in extreme weather and climate events: Observations, socioeconomic impacts, terrestrial ecological impacts, and model projections. Bulletin of the American Meteorological Society, 81(3), 413-416.

Frich, P., Alexander, L. V., Della-Marta, P., Gleason, B., Haylock, M., Klein Tank, A. M. G., \& Peterson, T. (2002). Observed coherent changes in climatic extremes during the second half of the twentieth century. Climate Research, 19(3), 193-212.

U.S. EPA, (2009). Assessment of the impacts of global change on regional US air quality: A synthesis of climate change impacts on ground-level ozone. USEP Agency, Washington, DC.

Shen, L., Mickley, L. J., \& Gilleland, E. (2016). Impact of increasing heat waves on US ozone episodes in the 2050s: Results from a multimodel analysis using extreme value theory. Geophysical Research Letters, 43(8), 4017-4025.

Air Quality Expert Group, (2005). Particulate Matter in the United Kingdom.

Filleul, L., Cassadou, S., Médina, S., Fabres, P., Lefranc, A., Eilstein, D., Le Tertre, A., Pascal, L., Chardon, B., Blanchard, M., Declercq, C., Jusot, J., Prouvost, H., \& Ledrans, M. (2006). The relation between temperature, ozone, and mortality in nine French cities during the heat wave of 2003. Environmental Health Perspectives, 114(9), 1344.

Stedman, J. R. (2004). The predicted number of air pollution related deaths in the UK during the August 2003 heatwave. Atmospheric Environment, 38(8), 1087-1090.

Carslaw, D. C., Beevers, S. D., \& Tate, J. E. (2007). Modelling and assessing trends in trafficrelated emissions using a generalised additive modelling approach. Atmospheric Environment, 41(26), 5289-5299. 
Pearce, J. L., Beringer, J., Nicholls, N., Hyndman, R. J., \& Tapper, N. J. (2011). Quantifying the influence of local meteorology on air quality using generalized additive models. Atmospheric Environment, 45(6), 1328-1336.

Vardoulakis, S., \& Heaviside, C. (2012). Health Effects of Climate Change in the UK 2012Current evidence, recommendations and research gaps. Health Protection Agency, UK.

Oke, T. R. (1973). City size and the urban heat island. Atmospheric Environment, 7(8), 769-779.

Heaviside, C., Cai, X. -M., \& Vardoulakis, S. (2015). The effects of horizontal advection on the urban heat island in Birmingham and the West Midlands, United Kingdom during a heatwave. Quarterly Journal of the Royal Meteorological Society, 141(689), 1429-1441.

Unwin, D. J. (1980). The synoptic climatology of Birmingham's urban heat island, 196574. Weather, 35(2), 43-50.

Qian, J., Hospodsky, D., Yamamoto, N., Nazaroff, W. W., \& Peccia, J. (2012). Size-resolved emission rates of airborne bacteria and fungi in an occupied classroom. Indoor Air, 22(4), 339351.

Katsouyanni, K., Touloumi, G., Samoli, E., Gryparis, A., Le Tertre, A., Monopolis, Y., Rossi, G., Zmirou, D., Ballester, F., Boumghar, A., Anderson, H. R., Wojtyniak, B., Paldy, A., Braunstein, R., Pekkanen, J., Schindler, C., \& Schwartz, J. (2001). Confounding and effect modification in the short-term effects of ambient particles on total mortality: Results from 29 European cities within the APHEA2 project. Epidemiology, 12(5), 521-531.

Chaxel, E., \& Chollet, J. -P. (2009). Ozone production from Grenoble city during the August 2003 heat wave. Atmospheric Environment, 43(31), 4784-4792.

Elminir, H. K. (2005). Dependence of urban air pollutants on meteorology. Science of the Total Environment, 350(1-3), 225-237.

Tressol, M., Ordonez, C., Zbinden, R., Brioude, J., Thouret, V., Mari, C., Nedelec, P., Cammas, J. -P., Smit, H., Patz, H.-W., \& Volz-Thomas, A. (2008). Air pollution during the 2003 European heat wave as seen by MOZAIC airliners. Atmospheric Chemistry and Physics, 8, 2133-2150.

Solberg, S., Hov, Ø., Søvde, A., Isaksen, I. S. A., Coddeville, P., De Backer, H., Forster, C., Orsolini, Y., \& Uhse, K. (2008). European surface ozone in the extreme summer 2003. Journal of Geophysical Research: Atmospheres, 113(D7).

Monks, P.S., Archibald, A. T., Colette, A., Cooper, O., Coyle, M., Derwent, R., Fowler, D., Granier, C., Law, K. S., Mills, G. E., Stevenson, D. S., Tarasova, O., Thouret, V., von Schneidermesser, E., Sommariva, R., Wild, O., \& Williams, M. L. (2015). Tropospheric ozone and its precursors from the urban to the global scale from air quality to short-lived climate forcer. Atmospheric Chemistry and Physics, 15(15), 8889-8973. 
Heal, M. R., Heaviside, C., Doherty, R. M., Vieno, M., Stevenson, D. S., \& Vardoulakis, S. (2013). Health burdens of surface ozone in the UK for a range of future scenarios. Environment International, 61, 36-44.

Huang, K., Zhuang, G., Lin, Y., Li, J., Sun, Y., Zhang, W., \& Fu, J. S. (2010). Relation between optical and chemical properties of dust aerosol over Beijing, China. Journal of Geophysical Research: Atmospheres, 115(D7).

Dawson, J. P., Adams, P. J., \& Pandis, S. N. (2007). Sensitivity of ozone to summertime climate in the eastern USA: A modeling case study. Atmospheric Environment, 41(7), 1494-1511.

Hewitt, C. N., \& Jackson, A. V. (2009). Atmospheric science for environmental scientists. John Wiley \& Sons.

Jacobson, M. Z. (2012). Air pollution and global warming: History, science, and solutions. Cambridge University Press.

Tai, A. P., Mickley, L. J., \& Jacob, D. J. (2010). Correlations between fine particulate matter $\left(\mathrm{PM}_{2.5}\right)$ and meteorological variables in the United States: Implications for the sensitivity of $\mathrm{PM}_{2.5}$ to climate change. Atmospheric Environment, 44(32), 3976-3984.

Massey, D., Kulshrestha, A., Masih, J., \& Taneja, A. B. E. J. (2012). Seasonal trends of PM10, $\mathrm{PM}_{5.0}, \mathrm{PM}_{2.5}$ \& $\mathrm{PM}_{1.0}$ in indoor and outdoor environments of residential homes located in NorthCentral India. Building and Environment, 47, 223-231.

Dore, C. J., Goodwin, J. W. L., Watterson, J. D., Murrells, T. P., Passant, N. R., Hobson, M. M., Haigh, K. E., Baggott, S. L., Pye, S. T., Coleman, P. J., \& King, K. R. (2003). UK emissions of air pollutants 1970 to 2001 .

Barlow, T. J., Boulter, P. G., McCrae, I. S., Sivell, P., Harrison, R. M., Carruthers, D., \& Stocker, J. (2007). Non-exhaust particulate matter emissions from road traffic: Summary report. Published project report PPR231.

Mues, A., Manders, A., Schaap, M., Kerschbaumer, A., Stern, R., \& Builtjes, P. (2012). Impact of the extreme meteorological conditions during the summer 2003 in Europe on particulate matter concentrations. Atmospheric Environment, 55, 377-391.

Kassomenos, P. A., Vardoulakis, S., Chaloulakou, A., Paschalidou, A. K., Grivas, G., Borge, R., \& Lumbreras, J. (2014). Study of $\mathrm{PM}_{10}$ and $\mathrm{PM}_{2.5}$ levels in three European cities: Analysis of intra and inter urban variations. Atmospheric Environment, 87, 153-163.

DEFRA, (2004). Air pollution in the UK: 2003 
Bibri, S. E., \& Krogstie, J. (2017). Smart sustainable cities of the future: An extensive interdisciplinary literature review. Sustainable Cities and Society, 31, 183-212. http://doi.org/10.1016/J.SCS.2017.02.016

McDonald, A. G., Bealey, W. J., Fowler, D., Dragosits, U., Skiba, U., Smith, R. I., ... Nemitz, E. (2007). Quantifying the effect of urban tree planting on concentrations and depositions of PM10 in two UK conurbations. Atmospheric Environment, 41(38), 8455-8467. http://doi.org/10.1016/J.ATMOSENV.2007.07.025

Mirzaei, P. A. (2015). Recent challenges in modeling of urban heat island. Sustainable Cities and Society, 19, 200-206. http://doi.org/10.1016/J.SCS.2015.04.001

Silva, B. N., Khan, M., \& Han, K. (2018). Towards sustainable smart cities: A review of trends, architectures, components, and open challenges in smart cities. Sustainable Cities and Society, 38, 697-713. http://doi.org/10.1016/J.SCS.2018.01.053

Yang, J., Yu, Q., \& Gong, P. (2008). Quantifying air pollution removal by green roofs in Chicago. Atmospheric Environment, 42(31), 7266-7273. http://doi.org/10.1016/j.atmosenv.2008.07.003

Simon, H., Reff, A., Wells, B., Xing, J., \& Frank, N. (2015). Ozone trends across the United States over a period of decreasing NOx and VOC emissions. Environmental Science and Technology, 49(1), 186-195. http://doi.org/10.1021/es504514z

Wałaszek, K., Kryza, M., \& Werner, M. (2018). The role of precursor emissions on ground level ozone concentration during summer season in Poland. Journal of Atmospheric Chemistry, 75(2), 181-204. http://doi.org/10.1007/s10874-017-9371-y

\section{LIST OF FIGURE CAPTIONS}

Fig. 1. Map of the United Kingdom and Ireland showing the location of the two UK air quality stations, Birmingham Tyburn (Urban) and Harwell (rural).

Fig. 2. Mean concentrations of air pollutants $\left(\mathrm{O}_{3}, \mathrm{NO}_{2}\right.$, and $\left.\mathrm{PM}_{10}\right)$ and temperature during heatwaves of August 2003.

Fig. 3. Mean concentrations of air pollutants $\left(\mathrm{O}_{3}, \mathrm{NO}_{2}\right.$, and $\left.\mathrm{PM}_{10}\right)$ and temperature during heatwaves of June to July $10^{\text {th }}, 2006$.

Fig. 4. Mean concentrations of air pollutants $\left(\mathrm{O}_{3}, \mathrm{NO}_{2}\right.$, and $\left.\mathrm{PM}_{10}\right)$ and temperature during heatwaves of July 2006.

Fig. 5. Mean concentrations of air pollutants $\left(\mathrm{O}_{3}, \mathrm{NO}_{2}\right.$, and $\left.\mathrm{PM}_{10}\right)$ and temperature during heatwaves of July 2013. 
Fig. 6. Correlation analysis of air pollutants $\left(\mathrm{O}_{3}, \mathrm{PM}_{10}\right.$, and $\left.\mathrm{NO}_{2}\right)$ and all intense heatwaves identified in 2003, 2006 and 2013.

\section{LIST OF TABLE TITLES}

Table 1 Heatwave periods, corresponding annual maximum temperatures and concentration of air pollutants (Ozone, $\mathrm{NO}_{2}$ and $\mathrm{PM}_{10}$ ) identified in 2003, 2005, 2006, 2008, 2010 and 2013 in rural areas

Table 2 Heatwave periods, corresponding annual maximum temperatures and concentration of air pollutants (Ozone, $\mathrm{NO}_{2}$ and $\mathrm{PM}_{10}$ ) identified in 2003, 2005, 2006, 2008, 2010 and 2013 in urban areas

Table 3 The mean concentration of air pollution $\left(\mathrm{O}_{3}, \mathrm{NO}_{2}\right.$, and $\left.\mathrm{PM}_{10}\right)$ and temperature in rural and urban spanning from May 2003 to September of 2013

Table 4 May to September averages of air pollution and temperature in rural and urban areas from 2003 to 2013

Table 5 Hottest month of the year and the frequency of hot days observed from 2003 to 2013 in rural and urban areas in Birmingham

Table 6 Comparison of the mean concentration of air pollutants $\left(\mathrm{O}_{3}, \mathrm{NO}_{2}\right.$, and $\left.\mathrm{PM}_{10}\right)$ and temperature between urban and rural sites during 2003, 2006 and 2013 heatwaves combined 


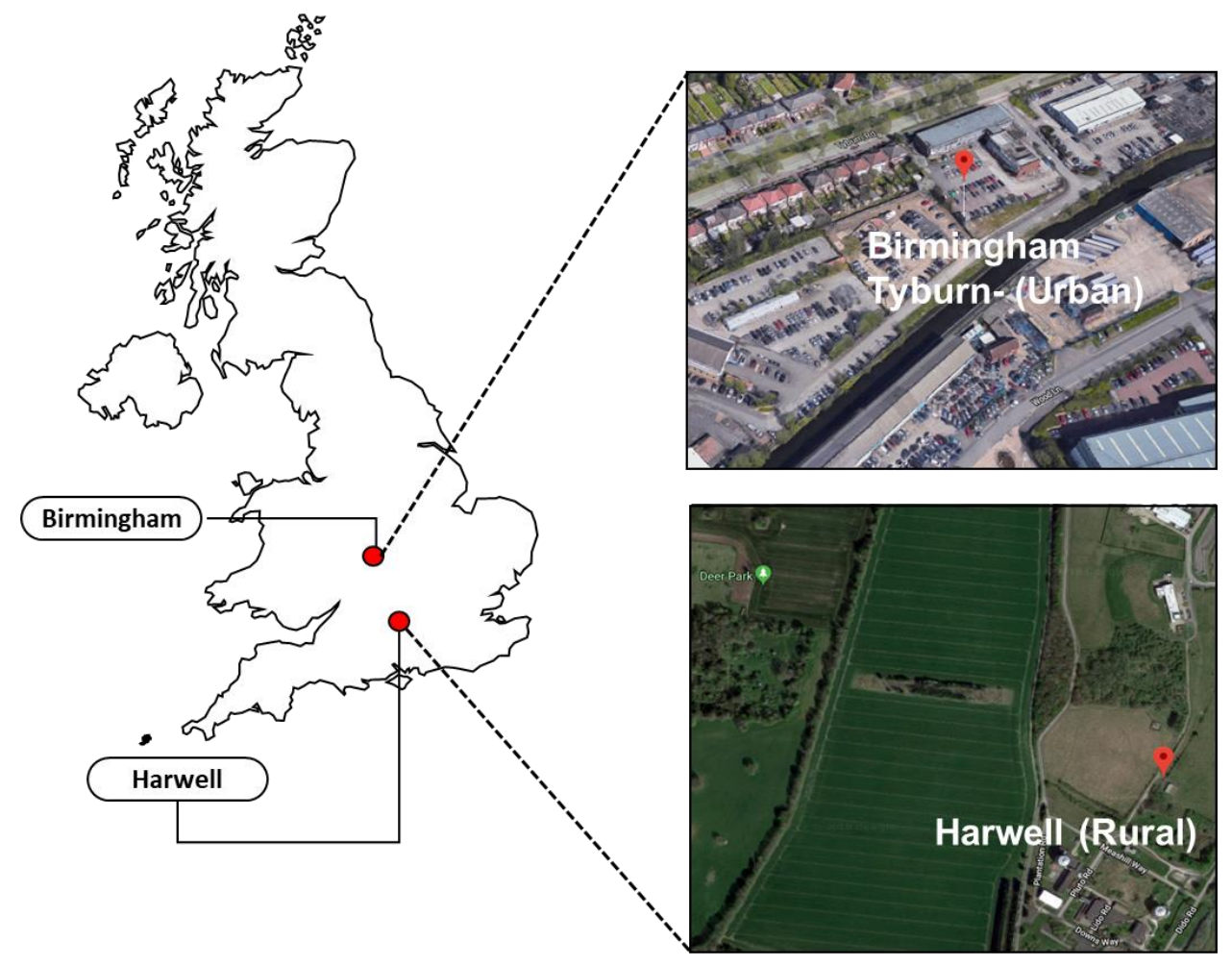

Fig. 1. Map of the United Kingdom and Ireland showing the location of the two UK air quality stations, Birmingham Tyburn (Urban) and Harwell (rural).

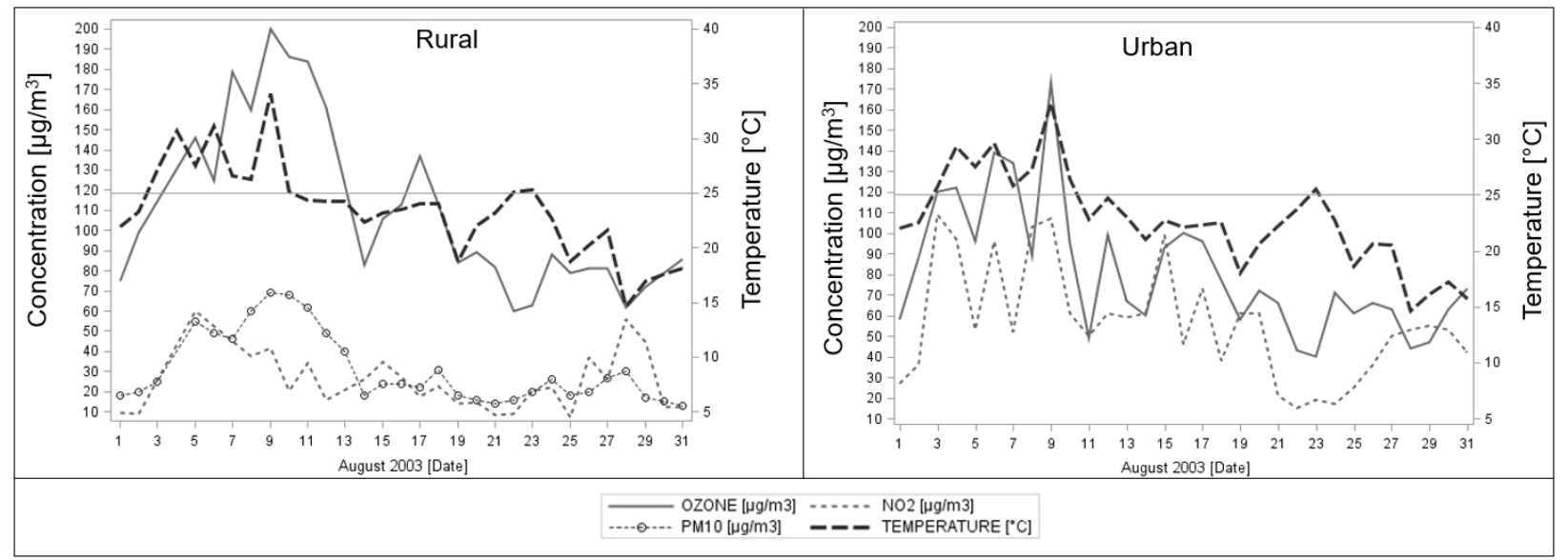

Fig. 2. Mean concentrations of air pollutants $\left(\mathrm{O}_{3}, \mathrm{NO}_{2}\right.$, and $\left.\mathrm{PM}_{10}\right)$ and temperature during heatwaves of August 2003. 


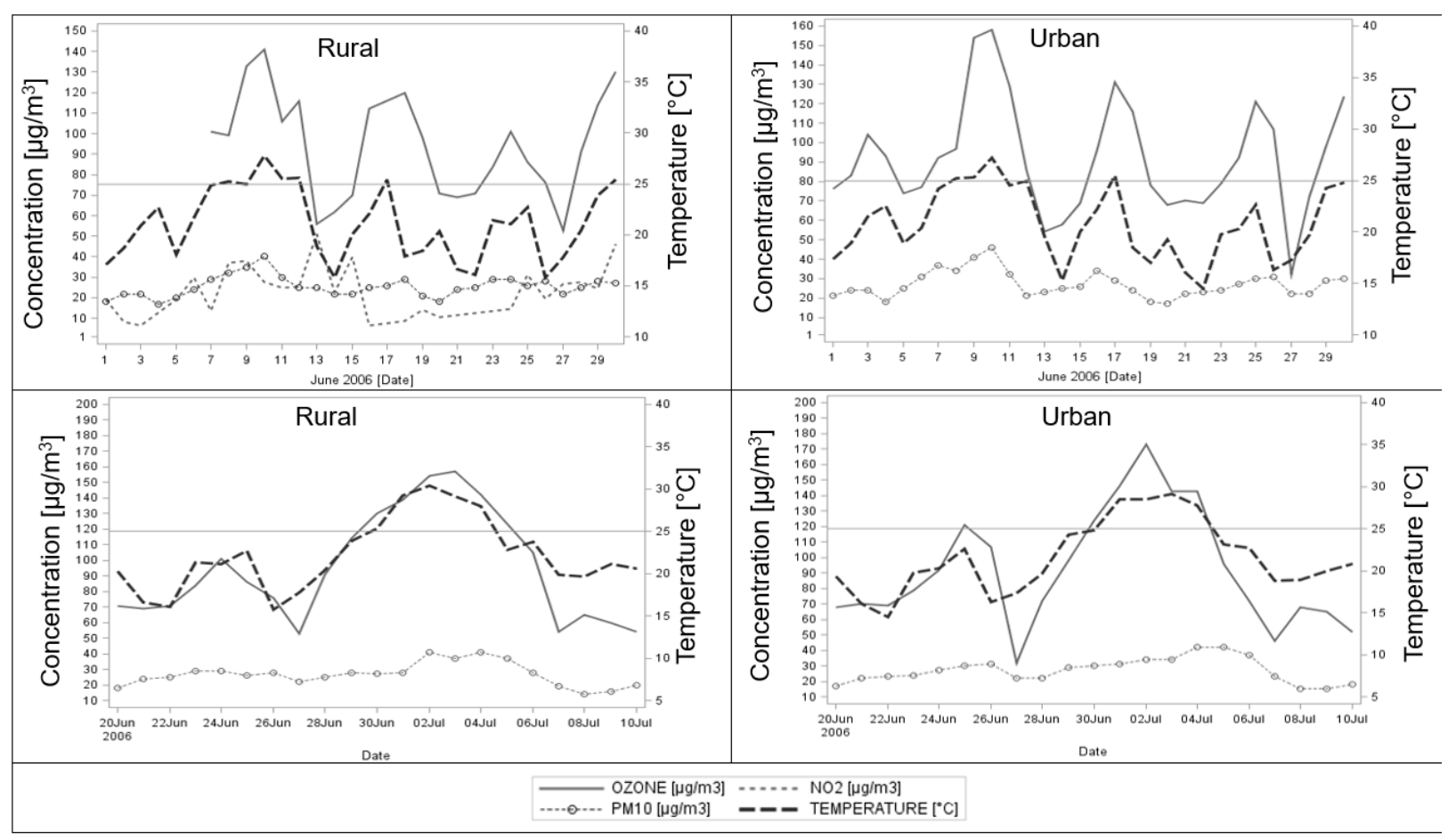

Fig. 3. Mean concentrations of air pollutants $\left(\mathrm{O}_{3}, \mathrm{NO}_{2}\right.$, and $\left.\mathrm{PM}_{10}\right)$ and temperature during heatwaves of June to July $10^{\text {th }}, 2006$.

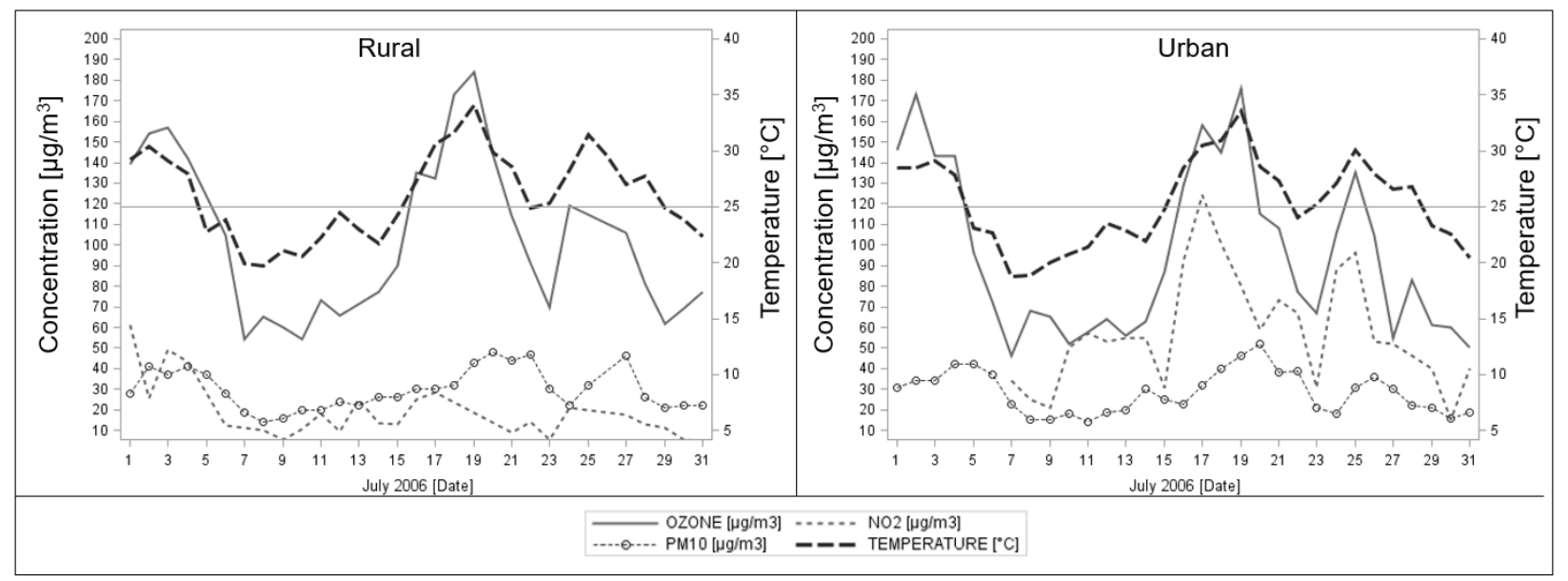

Fig. 4. Mean concentrations of air pollutants $\left(\mathrm{O}_{3}, \mathrm{NO}_{2}\right.$, and $\left.\mathrm{PM}_{10}\right)$ and temperature during heatwaves of July 2006. 


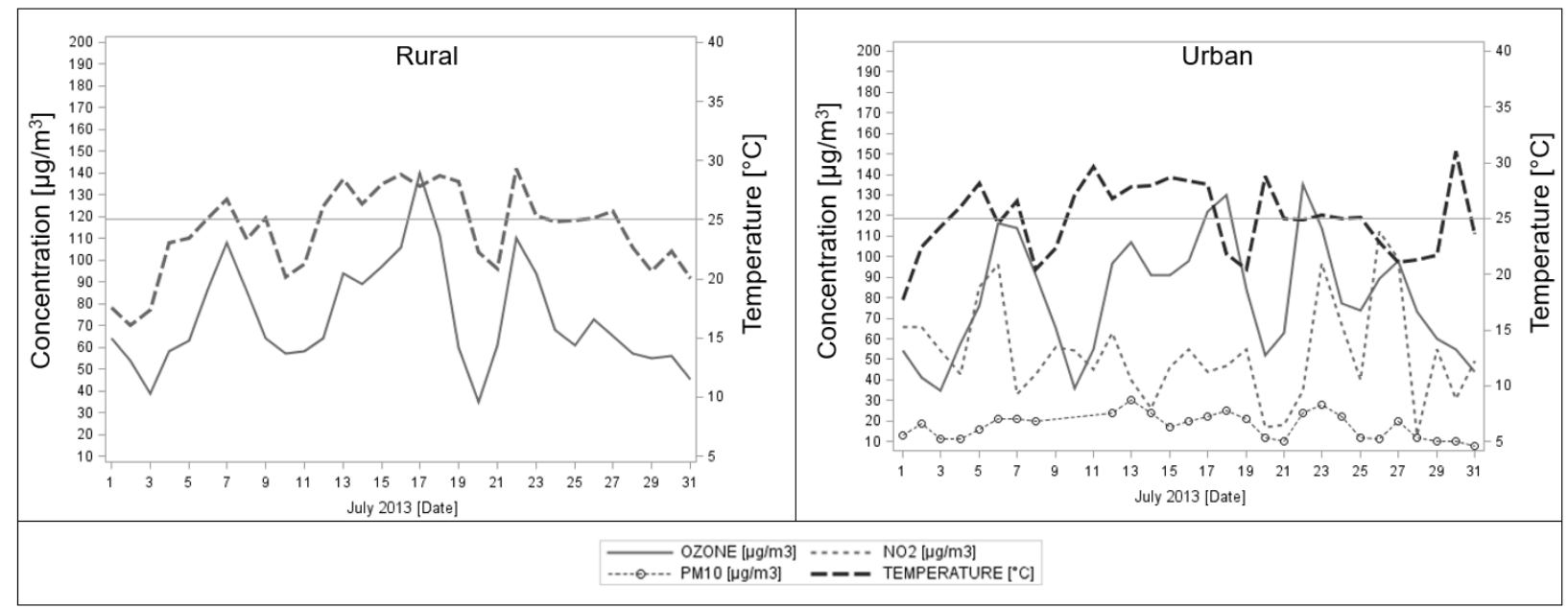

Fig. 5. Mean concentrations of air pollutants $\left(\mathrm{O}_{3}, \mathrm{NO}_{2}\right.$, and $\left.\mathrm{PM}_{10}\right)$ and temperature during heatwaves of July 2013. 

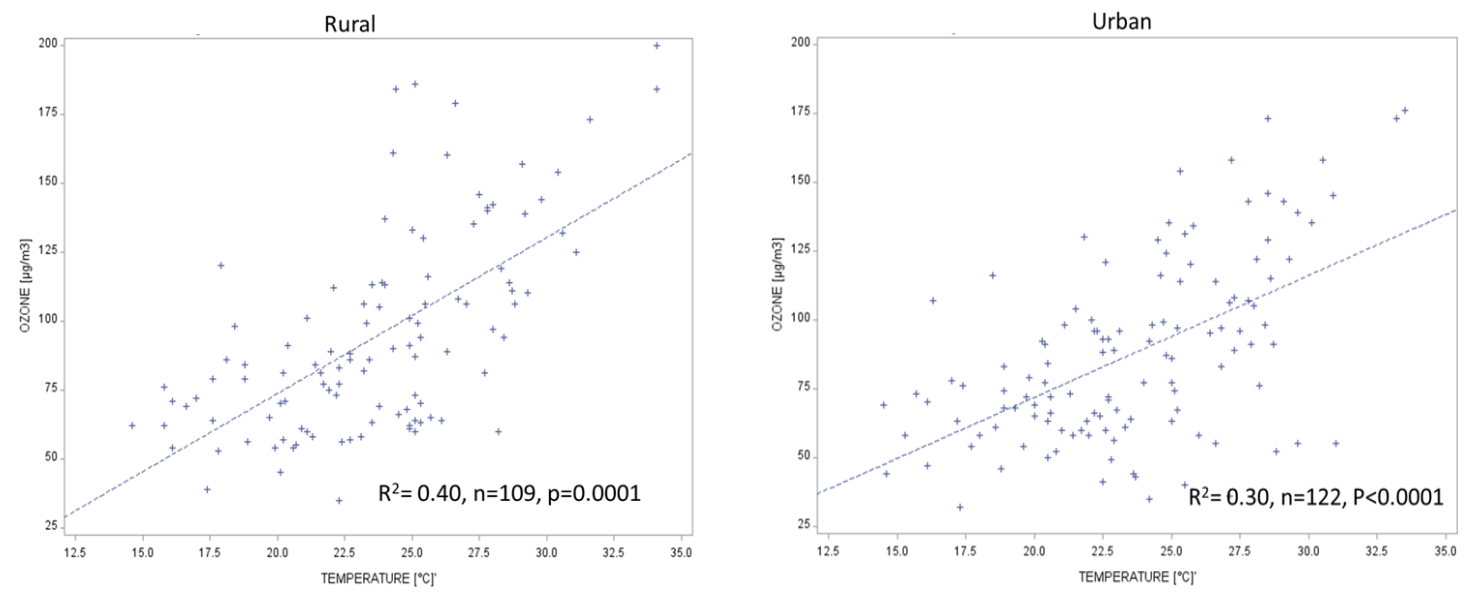

(a) Correlation analysis between $\mathrm{O}_{3}$ and heatwaves.
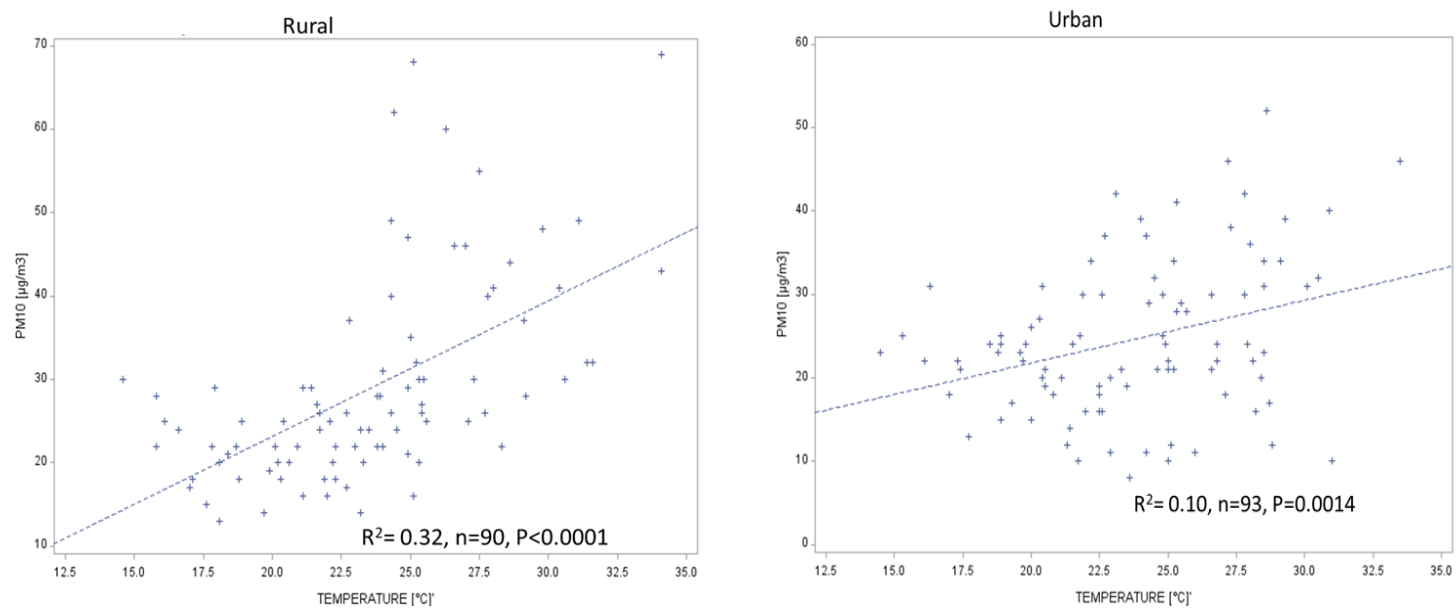

(b) Correlation analysis between $\mathrm{PM}_{10}$ and heatwaves.
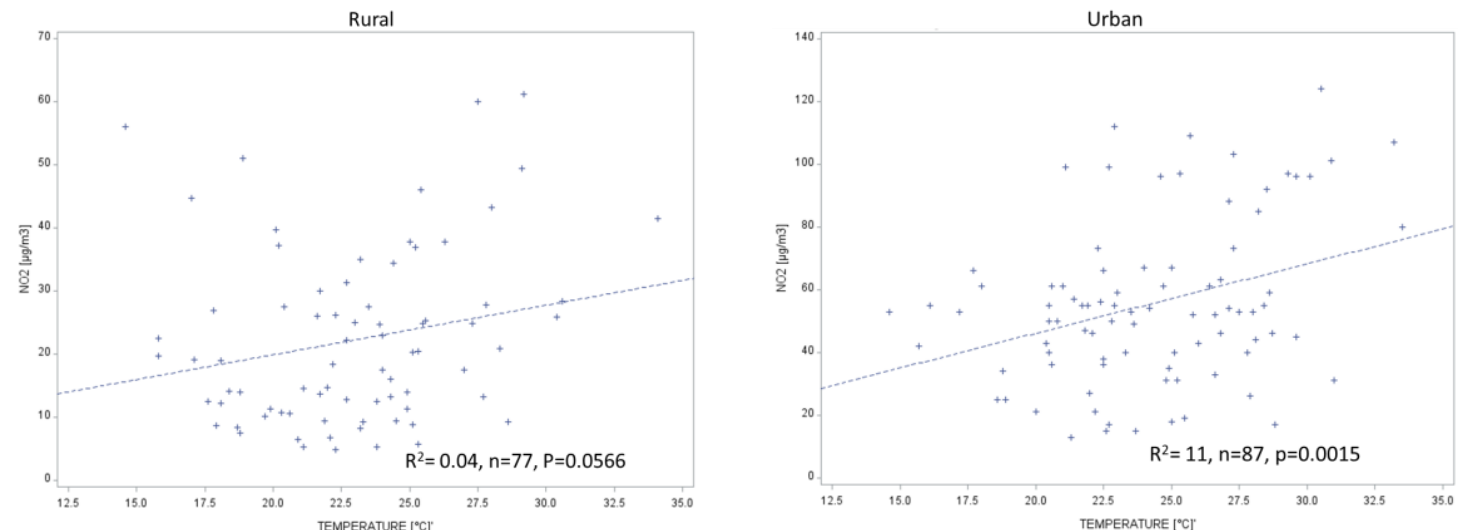

(c) Correlation analysis between $\mathrm{NO}_{2}$ and heatwaves.

Fig. 6. Correlation analysis of air pollutants $\left(\mathrm{O}_{3}, \mathrm{PM}_{10}\right.$, and $\left.\mathrm{NO}_{2}\right)$ and all intense heatwaves identified in 2003, 2006 and 2013 


\section{Table 1}

Heatwave periods, corresponding annual maximum temperatures and concentration of air pollutants (Ozone, $\mathrm{NO}_{2}$ and $\mathrm{PM}_{10}$ ) identified in 2003, 2005, 2006, 2008, 2010 and 2013 in rural areas

\begin{tabular}{|c|c|c|c|c|c|c|}
\hline Year & Month & Period & $\begin{array}{c}\text { Max. Temp } \\
{\left[{ }^{\circ} \mathbf{C}\right]}\end{array}$ & $\begin{array}{c}\mathbf{O}_{3} \\
{\left[\mu \mathrm{g} / \mathbf{m}^{3}\right]}\end{array}$ & $\begin{array}{c}\mathbf{P M}_{10} \\
{\left[\mu \mathrm{g} / \mathbf{m}^{3}\right]}\end{array}$ & $\begin{array}{c}\mathrm{NO}_{2} \\
{\left[\mu \mathrm{g} / \mathrm{m}^{3}\right]}\end{array}$ \\
\hline 2003 & August & $03-10^{\text {th }}$ & 34.1 & 200 & 69 & 41.4 \\
\hline 2005 & July & $10-14^{\text {th }}$ & 28.7 & 107 & 27 & 14.5 \\
\hline \multirow[t]{3}{*}{2006} & June & $08-12^{\text {th }}$ & 27.8 & 141 & 40 & 27.7 \\
\hline & June-July & $30-04^{\text {th }}$ & 30.4 & 154 & 41 & 25.8 \\
\hline & July & $17-29^{\text {th }}$ & 34.1 & 184 & 43 & - \\
\hline 2008 & July & $24-28^{\text {th }}$ & 27.1 & 108 & 21 & 26.4 \\
\hline 2010 & June & $26-30^{\text {th }}$ & 26.9 & 130 & 20 & 40.1 \\
\hline 2013 & July & $9-19^{\text {th }}$ & 28.8 & 106 & - & - \\
\hline
\end{tabular}

Table 2

Heatwave periods, corresponding annual maximum temperatures and concentration of air pollutants (Ozone, $\mathrm{NO}_{2}$ and $\mathrm{PM}_{10}$ ) identified in 2003, 2005, 2006, 2008, 2010 and 2013 in urban areas

\begin{tabular}{ccccccc}
\hline Year & Month & Period & $\begin{array}{c}\text { Max. Temp } \\
{\left[{ }^{\circ} \mathbf{C}\right]}\end{array}$ & $\begin{array}{c}\mathbf{O}_{3} \\
{\left[\boldsymbol{\mu g} / \mathbf{m}^{3}\right]}\end{array}$ & $\begin{array}{c}\mathbf{P M}_{10} \\
{\left[\boldsymbol{\mu g} / \mathbf{m}^{3}\right]}\end{array}$ & $\begin{array}{c}\mathbf{N O}_{2} \\
{\left[\boldsymbol{\mu g} / \mathbf{m}^{3}\right]}\end{array}$ \\
\hline 2003 & August & $02-10^{\text {th }}$ & 33.2 & 173 & - & 107 \\
2005 & July & $10-14^{\text {th }}$ & 28 & 103 & 28 & 56 \\
2006 & June & $12-17^{\text {th }}$ & 27.2 & 158 & 46 & - \\
& June-July & $30-04^{\text {th }}$ & 29.1 & 143 & 34 & - \\
2008 & July & $16-28^{\text {th }}$ & 33.5 & 176 & 46 & 80 \\
2010 & - & - & - & - & - & - \\
2013 & - & - & - & - & - & - \\
& July & $10-17^{\text {th }}$ & 28.7 & 91 & 17 & 46 \\
\hline
\end{tabular}

Table 3

The mean concentration of air pollution $\left(\mathrm{O}_{3}, \mathrm{NO}_{2}\right.$, and $\left.\mathrm{PM}_{10}\right)$ and temperature in rural and urban spanning from May 2003 to September of 2013

\begin{tabular}{lccccc}
\hline & \multicolumn{2}{c}{ RURAL } & \multicolumn{2}{c}{ URBAN } & \\
\cline { 2 - 5 } & Mean & Std & Mean & Std & p-value \\
\hline Daily max $\mathbf{N O}_{2}\left[\boldsymbol{\mu g} / \mathbf{m}^{3}\right]$ & 17.5 & 12.4 & 50.6 & 21.7 & $<0.0001$ \\
Daily max $\mathbf{O}_{\mathbf{3}}\left[\boldsymbol{\mu g} / \mathbf{m}^{3}\right]$ & 76.2 & 24.8 & 69.1 & 25.0 & $<0.0001$ \\
Daily mean $\mathbf{P M}_{\mathbf{1 0}}\left[\boldsymbol{\mu g} / \mathbf{m}^{3}\right]$ & 18.4 & 8.1 & 19.1 & 8.1 & 0.0765 \\
Daily max temperature $\left[{ }^{\circ} \mathbf{C}\right]$ & 19.4 & 4.1 & 19.0 & 4.0 & 0.0156 \\
\hline
\end{tabular}


Table 4

May to September averages of air pollution and temperature in rural and urban areas from 2003 to 2013

\begin{tabular}{|c|c|c|c|c|c|c|}
\hline \multirow{2}{*}{\multicolumn{2}{|c|}{ Year }} & \multicolumn{2}{|c|}{ RURAL } & \multicolumn{2}{|c|}{ URBAN } & \multirow[b]{2}{*}{ p-value } \\
\hline & & Mean & \pm SD & Mean & $\pm \mathrm{SD}$ & \\
\hline \multirow[t]{4}{*}{2003} & $\mathrm{NO}_{2}\left[\mu \mathrm{g} / \mathrm{m}^{3}\right]$ & 21.3 & 15.2 & 50.4 & 24.0 & $<0.0001$ \\
\hline & $\mathrm{O}_{3}\left[\mu \mathrm{g} / \mathrm{m}^{3}\right]$ & 97.5 & 31.3 & 80.9 & 27.5 & $<0.0001$ \\
\hline & $\mathrm{PM}_{10}\left[\mu \mathrm{g} / \mathrm{m}^{3}\right]$ & 21.5 & 11.2 & 20.7 & 7.8 & 0.5093 \\
\hline & Temperature $\left[{ }^{\circ} \mathrm{C}\right]$ & 20.4 & 4.4 & 19.7 & 4.3 & 0.2211 \\
\hline \multirow[t]{4}{*}{2004} & $\mathrm{NO}_{2}\left[\mu \mathrm{g} / \mathrm{m}^{3}\right]$ & 17.0 & 12.6 & 51.5 & 19.5 & $<0.0001$ \\
\hline & $\mathrm{O}_{3}\left[\mu \mathrm{g} / \mathrm{m}^{3}\right]$ & 82.6 & 19.5 & 63.2 & 16.2 & $<0.0001$ \\
\hline & $\mathrm{PM}_{10}\left[\mu \mathrm{g} / \mathrm{m}^{3}\right]$ & 20.5 & 7.8 & 21.1 & 8.2 & 0.4928 \\
\hline & Temperature $\left[{ }^{\circ} \mathrm{C}\right]$ & 19.2 & 3.6 & 18.7 & 3.5 & 0.2097 \\
\hline \multirow[t]{4}{*}{2005} & $\mathrm{NO}_{2}\left[\mu \mathrm{g} / \mathrm{m}^{3}\right]$ & 17.2 & 11.1 & 50.2 & 18.9 & $<0.0001$ \\
\hline & $\mathrm{O}_{3}\left[\mu \mathrm{g} / \mathrm{m}^{3}\right]$ & 72.7 & 18.5 & 66.1 & 21.8 & 0.0052 \\
\hline & $\mathrm{PM}_{10}\left[\mu \mathrm{g} / \mathrm{m}^{3}\right]$ & 19.4 & 5.3 & 20.6 & 5.9 & 0.0708 \\
\hline & Temperature $\left[{ }^{\circ} \mathrm{C}\right]$ & 19.6 & 4.1 & 19.0 & 4.0 & 0.2550 \\
\hline \multirow[t]{4}{*}{2006} & $\mathrm{NO}_{2}\left[\mu \mathrm{g} / \mathrm{m}^{3}\right]$ & 19.8 & 11.3 & 57.3 & 23.4 & $<0.0001$ \\
\hline & $\mathrm{O}_{3}\left[\mu \mathrm{g} / \mathrm{m}^{3}\right]$ & 82.6 & 28.3 & 73.5 & 31.0 & 0.0107 \\
\hline & $\mathrm{PM}_{10}\left[\mu \mathrm{g} / \mathrm{m}^{3}\right]$ & 20.2 & 7.9 & 24.1 & 8.9 & 0.3451 \\
\hline & Temperature $\left[{ }^{\circ} \mathrm{C}\right]$ & 20.8 & 4.5 & 20.3 & 4.4 & 0.2378 \\
\hline \multirow[t]{4}{*}{2007} & $\mathrm{NO}_{2}\left[\mu \mathrm{g} / \mathrm{m}^{3}\right]$ & 17.0 & 12.6 & 51.5 & 19.5 & $<0.0001$ \\
\hline & $\mathrm{O}_{3}\left[\mu \mathrm{g} / \mathrm{m}^{3}\right]$ & 82.6 & 19.6 & 63.2 & 16.2 & $<0.0001$ \\
\hline & $\mathrm{PM}_{10}\left[\mu \mathrm{g} / \mathrm{m}^{3}\right]$ & 20.5 & 7.8 & 21.1 & 8.2 & 0.4928 \\
\hline & Temperature $\left[{ }^{\circ} \mathrm{C}\right]$ & 19.2 & 3.6 & 18.7 & 3.5 & 0.2097 \\
\hline \multirow[t]{4}{*}{2008} & $\mathrm{NO}_{2}\left[\mu \mathrm{g} / \mathrm{m}^{3}\right]$ & 18.8 & 13.7 & 53.5 & 19.2 & $<0.0001$ \\
\hline & $\mathrm{O}_{3}\left[\mu \mathrm{g} / \mathrm{m}^{3}\right]$ & 70.1 & 21.4 & 69.6 & 25.1 & 0.8660 \\
\hline & $\mathrm{PM}_{10}\left[\mu \mathrm{g} / \mathrm{m}^{3}\right]$ & 16.4 & 7.5 & 18.0 & 9.9 & 0.1309 \\
\hline & Temperature $\left[{ }^{\circ} \mathrm{C}\right]$ & 18.6 & 3.1 & 18.4 & 3.0 & 0.6182 \\
\hline \multirow[t]{4}{*}{2009} & $\mathrm{NO}_{2}\left[\mu \mathrm{g} / \mathrm{m}^{3}\right]$ & 13.2 & 9.7 & 44.1 & 17.4 & $<0.0001$ \\
\hline & $\mathrm{O}_{3}\left[\mu \mathrm{g} / \mathrm{m}^{3}\right]$ & 69.6 & 19.3 & 62.7 & 22.1 & 0.0044 \\
\hline & $\mathrm{PM}_{10}\left[\mu \mathrm{g} / \mathrm{m}^{3}\right]$ & 15.3 & 4.9 & 16.1 & 5.5 & 0.1883 \\
\hline & Temperature $\left[{ }^{\circ} \mathrm{C}\right]$ & 18.8 & 3.3 & 18.3 & 3.3 & 0.1806 \\
\hline
\end{tabular}




\begin{tabular}{|c|c|c|c|c|c|c|}
\hline \multirow[t]{4}{*}{2010} & $\mathrm{NO}_{2}\left[\mu \mathrm{g} / \mathrm{m}^{3}\right]$ & 15.6 & 11.5 & 53.3 & 24.7 & $<0.0001$ \\
\hline & $\mathrm{O}_{3}\left[\mu \mathrm{g} / \mathrm{m}^{3}\right]$ & 74.9 & 17.5 & 65.6 & 19.3 & $<0.0001$ \\
\hline & $\mathrm{PM}_{10}\left[\mu \mathrm{g} / \mathrm{m}^{3}\right]$ & 13.0 & 3.5 & - & - & - \\
\hline & Temperature $\left[{ }^{\circ} \mathrm{C}\right]$ & 18.9 & 4.1 & 18.2 & 3.8 & 0.1082 \\
\hline \multirow[t]{4}{*}{2011} & $\mathrm{NO}_{2}\left[\mu \mathrm{g} / \mathrm{m}^{3}\right]$ & 13.3 & 8.3 & 44.8 & 18.0 & $<0.0001$ \\
\hline & $\mathrm{O}_{3}\left[\mu \mathrm{g} / \mathrm{m}^{3}\right]$ & 75.2 & 16.8 & 64.0 & 15.7 & $<0.0001$ \\
\hline & $\mathrm{PM}_{10}\left[\mu \mathrm{g} / \mathrm{m}^{3}\right]$ & 15.3 & 5.1 & 15.6 & 6.9 & 0.7379 \\
\hline & Temperature $\left[{ }^{\circ} \mathrm{C}\right]$ & 19.3 & 3.1 & 18.4 & 3.0 & 0.0099 \\
\hline \multirow[t]{4}{*}{2012} & $\mathrm{NO}_{2}\left[\mu \mathrm{g} / \mathrm{m}^{3}\right]$ & 16.0 & 9.6 & 44.8 & 16.0 & $<0.0001$ \\
\hline & $\mathrm{O}_{3}\left[\mu \mathrm{g} / \mathrm{m}^{3}\right]$ & 75.0 & 20.1 & 61.5 & 20.0 & $<0.0001$ \\
\hline & $\mathrm{PM}_{10}\left[\mu \mathrm{g} / \mathrm{m}^{3}\right]$ & 16.5 & 6.6 & 17.0 & 6.6 & 0.4970 \\
\hline & Temperature $\left[{ }^{\circ} \mathrm{C}\right]$ & 17.8 & 4.1 & 17.5 & 4.1 & 0.4175 \\
\hline \multirow[t]{4}{*}{2013} & $\mathrm{NO}_{2}\left[\mu \mathrm{g} / \mathrm{m}^{3}\right]$ & 10.1 & 7.8 & 46.9 & 21.8 & $<0.0001$ \\
\hline & $\mathrm{O}_{3}\left[\mu \mathrm{g} / \mathrm{m}^{3}\right]$ & 66.9 & 20.6 & 66.6 & 22.1 & 0.9088 \\
\hline & $\mathrm{PM}_{10}\left[\mu \mathrm{g} / \mathrm{m}^{3}\right]$ & 24.4 & 8.3 & 15.5 & 6.5 & 0.0006 \\
\hline & Temperature $\left[{ }^{\circ} \mathrm{C}\right]$ & 19.1 & 4.6 & 19.2 & 4.5 & 0.7894 \\
\hline
\end{tabular}




\section{Table 5}

Hottest month of the year and the frequency of hot days observed from 2003 to 2013 in rural and urban areas in Birmingham

\begin{tabular}{ccccc}
\hline & \multicolumn{2}{c}{ RURAL } & \multicolumn{2}{c}{ URBAN } \\
\cline { 2 - 5 } Year & Hottest month & Frequency: n (\%) & Hottest month & Frequency: n (\%) \\
\hline $\mathbf{2 0 0 3}$ & August & $10(45.5)$ & August & $9(47.4)$ \\
$\mathbf{2 0 0 4}$ & August & $5(45.5)$ & August & $4(40.0)$ \\
$\mathbf{2 0 0 5}$ & July & $6(23.5)$ & July & $6(42.9)$ \\
$\mathbf{2 0 0 6}$ & July & $16(55.2)$ & July & $16(50.0)$ \\
$\mathbf{2 0 0 7}$ & September & $2(100)$ & August & $2(100)$ \\
$\mathbf{2 0 0 8}$ & July & $6(85.7)$ & July & $3(75.0)$ \\
$\mathbf{2 0 0 9}$ & June & $3(50.0)$ & June & $3(60.0)$ \\
$\mathbf{2 0 1 0}$ & June & $7(58.3)$ & June & $3(75.0)$ \\
$\mathbf{2 0 1 1}$ & August & $4(44.4)$ & August & $2(40.0)$ \\
$\mathbf{2 0 1 2}$ & July & $2(100)$ & July & $2(66.7)$ \\
$\mathbf{2 0 1 3}$ & July & $15(88.2)$ & July & $17(94.4)$ \\
\hline
\end{tabular}




\section{Table 6}

Comparison of the mean concentration of air pollutants $\left(\mathrm{O}_{3}, \mathrm{NO}_{2}\right.$, and $\left.\mathrm{PM}_{10}\right)$ and temperature between urban and rural sites during 2003, 2006 and 2013 heatwaves combined

\begin{tabular}{|c|c|c|c|c|}
\hline Heatwaves & & RURAL & URBAN & p-value \\
\hline Year & & Mean \pm SD & Mean \pm SD & \\
\hline \multirow{4}{*}{2003} & $\mathrm{NO}_{2}\left[\mu \mathrm{g} / \mathrm{m}^{3}\right]$ & $21.3 \pm 15.2$ & $50.4 \pm 24.0$ & $<0.0001$ \\
\hline & $\mathrm{O}_{3}\left[\mu \mathrm{g} / \mathrm{m}^{3}\right]$ & $97.5 \pm 31.3$ & $80.9 \pm 27.5$ & $<0.0001$ \\
\hline & $\mathrm{PM}_{10}\left[\mu \mathrm{g} / \mathrm{m}^{3}\right]$ & $21.5 \pm 11.2$ & $20.7 \pm 7.8$ & 0.5093 \\
\hline & Temperature $\left[{ }^{\circ} \mathrm{C}\right]$ & $20.4 \pm 4.4$ & $19.7 \pm 4.3$ & 0.2211 \\
\hline \multirow{4}{*}{2006} & $\mathrm{NO}_{2}\left[\mu \mathrm{g} / \mathrm{m}^{3}\right]$ & $19.8 \pm 11.3$ & $57.3 \pm 23.4$ & $<0.0001$ \\
\hline & $\mathrm{O}_{3}\left[\mu \mathrm{g} / \mathrm{m}^{3}\right]$ & $82.6 \pm 28.3$ & $73.5 \pm 31.0$ & 0.0107 \\
\hline & $\mathrm{PM}_{10}\left[\mu \mathrm{g} / \mathrm{m}^{3}\right]$ & $20.2 \pm 7.9$ & $24.1 \pm 8.9$ & 0.3451 \\
\hline & Temperature $\left[{ }^{\circ} \mathrm{C}\right]$ & $20.8 \pm 4.5$ & $20.3 \pm 4.4$ & 0.2378 \\
\hline \multirow{4}{*}{2013} & $\mathrm{NO}_{2}\left[\mu \mathrm{g} / \mathrm{m}^{3}\right]$ & $10.1 \pm 7.8$ & $46.9 \pm 21.8$ & $<0.0001$ \\
\hline & $\mathrm{O}_{3}\left[\mu \mathrm{g} / \mathrm{m}^{3}\right]$ & $66.9 \pm 20.6$ & $66.6 \pm 21.1$ & 0.9088 \\
\hline & $\mathrm{PM}_{10}\left[\mu \mathrm{g} / \mathrm{m}^{3}\right]$ & $24.4 \pm 8.3$ & $15.5 \pm 6.5$ & 0.0006 \\
\hline & Temperature $\left[{ }^{\circ} \mathrm{C}\right]$ & $19.1 \pm 4.6$ & $19.2 \pm 4.5$ & 0.7894 \\
\hline
\end{tabular}

